студенти мають змогу переглянути лекцію, якщо вони не були присутні на ній. Підвищення ефективності технологій можливе тільки за умови переважання на всіх етапах навчального процесу творчої, пошукової діяльності студентів, де відбуватиметься відхід від жорсткої уніфікації, однаковості цілей, змісту, методів, засобів і організаційних форм навчання, до розвитку та виховання індивідуалізації та диференціації самої навчально-пізнавальної діяльності. [3] Лише у цьому випадку, ми матимемо освічену націю, здатну мислити та творити нову історію.

\title{
Література:
}

1. Власенко С.П. Особливості становлення сучасної багаторівневої освіти вчителів початкових класів. - 2002 [Електронний ресурс]. Режим доступу : http://enpuir.npu.edu.ua/bitstream/handle/123456789/ 7893/Vlasenko.pdf?sequence=1\&isAllowed=y

2. Конституція України. Закон України від 28. 06. 1996 № 254к/96ВР // Відомості Верховної Ради України. -1996. - Режим доступу: https://zakon.rada.gov.ua/laws/show/254к/96-вр\#Text

3. Кравцова I. А. Особливості багаторівневої системи освіти в сучасному вузі і ідеї болонського процесу. - Криворізький державний педагогічний університет. - м Кривий Ріг. - 2015.

4. Таланчук Петро. Сформуй осердя свого щастя / П.М. Таланчук К. : Університет «Україна», 2014. - 79 с.

5. Law Nancy. Technology-enhanced innovative pedagogy: The challenge.- University of Hong Kong. Understanding innovative pedagogies: key themes to analyze new approaches to teaching and learning. - 2018. P. 116-134

DOI https://doi.org/10.30525/978-9934-26-114-5-68

\section{МАГІСТЕРСЬКА ПІДГОТОВКА ПЕРЕКЛАДАЧІВ В УНІВЕРСИТЕТАХ БЕЛЬГІї}

\author{
Чернова Ю. А. \\ викладач кафедри теорї та практики перекладу \\ Одеський національний університет імені I. І. Мечникова \\ м. Одеса, Україна
}

В умовах інтеграції України в європейський освітній простір зросла необхідність у фахівцях з іноземної мови, що зможуть забезпечити 
необхідний високий рівень міжнародної комунікації. Це призвело до поширення попиту на програми підготовки перекладачів, особливо на рівні магістратури [2; 4]. Зважаючи на те, що модернізація програм магістерської підготовки перекладачів проводиться в межах європейського освітнього простору, вивчення кращих освітніх практик 3 міжнародного досвіду є актуальним для вдосконалення діяльності вітчизняних закладів вищої освіти.

Згідно досвіду багатьох європейських країн, професійна підготовка майбутніх перекладачів в університетах здійснюється за двома основними типами освітніх програм:

- програмами повної вищої освіти з тривалістю навчання зазвичай 5 років та послідовним здобуттям ступенів бакалавра та магістра;

- магістерськими програми, які функціонують незалежно від бакалаврських, передбачаючи два (рідше один) роки грунтовної й спеціалізованої підготовки студентів, які до вступу отримали ступінь бакалавра у певній галузі знань [3].

Унаслідок такого розподілу, у різних європейських закладах вищої освіти програми, націлені на підготовку майбутніх перекладачів, можуть суттєво відрізнятися залежно від їх змісту та форм, професійного спрямування, способів організації навчального процесу, методики й технологій викладання загальних та фахових дисциплін тощо. У деяких університетах Європи магістерські програми для здобуття фаху перекладача передбачають вивчення двох та більше іноземних мов [5]. Крім того, існує велика кількість програм, які, окрім мовних і перекладацьких дисциплін, зокрема, теорії, історії та практики перекладу, залучають здобувачів до освоєння комп'ютерної техніки та програмного забезпечення, опанування новітніми технологіями, профільних та гуманітарних дисциплін, тренінгу навичок ділового спілкування. Такі освітні програми мають на меті не тільки підготовку фахівців із широким колом професійної перекладацької компетентності, але й набуття ними грунтовної профільної спеціалізації, оскільки спрямовані на задоволення конкретних потреб ринку перекладацьких послуг i передбачають наявність спеціалізованих дисциплін, що надають змогу додатково отримати необхідні знання у сфері майбутньої професійної діяльності перекладача. Іноді для зарахування на навчання за такими програмами потрібно попередньо отримати вищу освіту у сфері спеціалізації, щонайменше на рівні бакалаврату [1, с. 160].

Загалом, система повної вищої освіти передбачає набуття майбутніми перекладачами грунтовної мовної та комунікативної компетенцій, на основі яких формуються професійно важливі якості, 
навички й уміння фахівця, здатного до ефективної роботи в сфері перекладацьких послуг, відповідно до обраної спеціалізації: усний/ письмовий переклад, літературний/науковий, технічний/юридичний переклад, до обраної сфери професійної діяльності: машинобудівництво/галузь нафто-і газодобування, фармація/харчова промисловість тощо [4, с. 83].

В означеному контексті нашу увагу привернув інноваційний досвід університетів Бельгії з професійної підготовки майбутніх перекладачів. Суттєво, що складні історичні та політичні умови розвитку Королівства Бельгії, яке адміністративно поділено на три територіальні громади: Французьку, Фламандську та Німецькомовну 3 їх законодавчими та виконавчими інститутами, сприяли створенню практично незалежних систем вищої освіти, які здійснюються на французькій, голландській і німецькій мовах. Свобода законодавства і демократизм держави у питаннях вищої освіти дають можливість закладам вищої освіти мати надзвичайно широкі міжнародні контакти, а також запозичувати 3 міжнародного досвіду найкращі освітні практики, чому сприяє перетворення Брюсселя у центр діяльності керівних організацій СС [5, с. 18-19].

Слід зазначити, що в Бельгії основи теорії та практики перекладу як самостійних дисциплін почали закладатися 3 початку 60-х років XX століття, коли у 1962 році було засновано Школу міжнародних перекладачів у м. Монс, яка була однією 3 перших організацій, діяльність якої була спрямована на розробку спеціальних технологій навчання професійних перекладачів. 3 цього часу професійна підготовка усних і письмових перекладачів в Бельгії почала здійснюватися за незалежними магістерськими програмами, які до сьогодні успішно впроваджуються в найбільш відомих закладах вищої освіти: Університеті Сен-Луі, Вільному Брюссельському університеті, Лувенському католицькому університеті, Університеті Монсу та інших.

Натомість, освітні програми професійної підготовки майбутніх перекладачів в означених бельгійських університетах розрізняються передусім за спеціалізацією: в кожному університеті є окремі програми підготовки фахівців з усного та письмового перекладу. Притаманним також $\epsilon$ те, що програми підготовки перекладачів відрізняються відповідно до обраної сфери їх професійної діяльності: міжкультурна комунікація, технічна документація, економіка, медицина, політика, право, наука чи література. При цьому, всі діючі магістерські освітні програми забезпечують оволодіння майбутніми перекладачами двома робочими мовами, які самостійно обираються ними. Першою мовою $є$ англійська, французька або німецька, в якості другої мови можна 
обрати італійську, іспанську, китайську, арабську, нідерландську, російську, французьку, англійську або німецьку (в залежності від обраної першої мови). В певних університетах також є можливість обрати в якості другої мови мову жестів.

Професійна підготовка майбутніх перекладачів триває два роки i включає такі складові:

- універсальну, в яку входять профільні та загальні дисципліни, які через переважання нових освітніх, проектних та інноваційнокомунікативних технологій, гарантують набуття ними знань, стратегій та навичок, необхідних для обраного виду перекладу;

- вибіркову, представлену додатковими навчальними дисциплінами або новітніми елективними курсами за вибором;

- обов'язкове стажування за спеціальністю тривалістю не менше 20 кредитів ECTS, організоване у співпраці 3 міжнародними організаціями (ООН, СС, Рада Свропи, ЮНЕСКО) або організаціями в некомерційному секторі, після завершення якого студентам видається сертифікат [3].

Основною формою атестації майбутніх перекладачів при виконанні ними освітніх програм визнається кваліфікаційна магістерська робота, хоча в деяких закладах вищої освіти випускники магістерських програм для підтвердження своєї кваліфікації додатково повинні скласти атестаційні екзамени. Після здобуття диплома магістра з перекладу, який визнається у всіх країнах Євросоюзу, випускники магістерських програм мають право працювати в галузі фрілансу, мультимедіа, субтитрів; управляти перекладацькими проектами; бути локаторами веб-сайтів або відеоігор. Вони також можуть проявити свої навички в літературній сфері або перекладати каталоги виставок, філософські твори, або стати співробітниками спеціалізованих перекладацьких агенцій, транснаціональних компаній і видавництв, підприємств 3 виробництва аудіовізуальних матеріалів. Крім того, після проходження фахового конкурсу магістри-перекладачі можуть обіймати посади в перекладацьких службах міжнародних організацій (ЄС, НАТО, ООН та ін.) [2, 3, 4].

Отже, для України важливо вдосконалити магістерські програми 3 підготовки перекладачів, враховуючи як сучасні освітянські тенденції до спеціалізації перекладацької діяльності, так і максимально ефективно впроваджуючи позитивні аспекти зарубіжного, зокрема, бельгійського досвіду.

На відміну від університетів Бельгії, в Україні готувати професійних перекладачів почали у $70-\mathrm{x}$ роках $\mathrm{XX}$ століття, провідною спеціалізацією діяльності яких був воєнний фах (Харківський 
державний університет) [1, с. 158-159]. На сучасному етапі підготовка перекладачів здійснюється у провідних закладах вищої освіти (Київский національный університет імени Тараса Шевченка, Київський національний лінгвістичний університет, Київський університет імені Бориса Грінченка, Луганський національний університет імені Тараса Шевченка, Львівський національний університет Одеський національний університет імені I.I. Мечникова, Харківський національний університет імені В. Н. Каразіна).

Проаналізувавши діючі освітні програми означених вище університетів за спеціальністю 035, очевидно, що вони на рівні системи «бакалаврат (4 роки навчання) - магістратура (1,5-2 роки навчання)» здебільшого гарантують набуття випускниками інтегрованої кваліфікації: філолог, викладач іноземних мов, перекладач [5]. Лише останнім часом в цих університетах розпочалося ліцензування й акредитація магістерських освітніх програм за спеціалізацією «Переклад», навчання на яких здійснюється державною або англійською/другою мовами, передбачаючи обов'язкове проходження перекладацької практики.

\section{Література:}

1. Мартинюк О.В. Професійна підготовка перекладачів у контексті глобалізаційних та інтеграційних процесів. Педагогічний дискурс. 2010. Вип. 7. С. 157-161.

2. École de Traduction et Interprétation ISTI - Cooremans - Faculté de Lettres,Traduction et Communication (ulb.be). URL: https://ltc.ulb.be/nosdepartements-d-enseignement/ecole-de-traduction-et-interpretation-isticooremans-1

3. L'offre de formations - Faculté / FTI-EII (umons.ac.be). URL: https://web.umons.ac.be/fti-eii/fr/loffre-de-formations/

4. Traduction et interprétation | UCLouvain. URL: https://uclouvain.be/ $\mathrm{fr} /$ facultes/fial/traduction-et-interpretation.html

5. http://onu.edu.ua/uk/ 